DOI https://doi.org/10.30525/978-9934-26-075-9-20

\title{
РІДКІСНИЙ ВИПАДОК АРТЕРИЇТУ ТАКАЯСУ 3 ОДНОСТОРОННІМ СИМПТОМОМ «БАРАБАННИХ ПАЛИЧОК»
}

\author{
Петрова С. C. \\ студентка 5 курсу 3 медичного факультету \\ Харківський національний медичний університет
}

Макаренко Д. О.

студентка 5 курсу 3 медичного факультету

Харківський національний медичний університет

\section{Шапаренко О. В.}

асистент кафедри внутрішньої медицини № 2, клінічної імунології та алергології імені академіка Л. Т. Малої

Харківський національний медичний університет м. Харків, Україна

Актуальність. На даний момент структура захворюваносты істотно змінилась. У минулому залишились захворювання, які забрали життя сотень тисяч людей: чума, холера, оспа, іспанка. Однак на їх місці з'явились сучасні хвороби суспільства - розлади адаптації, неврози, синдром хронічної втоми та ін. Серед цих хвороб особливе місце займають аутоімунні захворюванн- група хвороб з остаточно не визначеною етіологією, в основі якої лежить аутоагресія імунної системи проти тканини людини. Досі ряд питань щодо даної групи хвороб залишається не 3'ясованим, що робить цю проблему актуальною для новітньої медицини.

Артеріїт Такаясу (АТ) - це гранулематозний артеріїт, що вражає великі судини, переважно аорту та ії основні гілки $[1$, с.5]. Запалення артерій, що спричиняє пошкодження ендотелію, може призвести до потовщення стінки судини, закупорки судин та утворення тромбів. Як наслідок, спричинена ішемія може призвести до інвалідизації пацієнта. На початку захворювання симптоми неспецифічні: лихоманка, втома, артралгія, міалгія та втрата ваги, тому дігностика данного захворювання утруднена [1, с. 26].

АТ найчастіше зустрічається серед жінок, і становить понад 90\% випадків. Частота АТ $\epsilon$ найвищою на четвертому десятку життя. 
Етіологія АТ досі до кінця не зрозуміла, але відомо, що деякі інфекції, зокрема мікобактерія туберкульозу, пов'язані з патогенезом АТ [2, с. 7].

Мета дослідження. Розглянути нетипові прояв артеріїту Такаясу на прикладі клінічного випадку.

Матеріали та методи. Робота була проведена на базі Кафедри внутрішньої медицини №2, клінічної імунології та алергології ім. академіка Л.Т. Малої. Використані методи: клінічне обстеження, рентгенографія, магнітно-резонансна ангіографія.

Клінічний випадок

24-річна жінка звернулась до лікарні зі скаргами на артралгію, нездужання та поганий апетит протягом останніх 3 місяців. Хвора стверджувала, що тиждень тому у неї був епізод тимчасової втрати свідомості, який вирішився самостійно, було припущено, що це вазовагальний синкоп.

Під час обстеження було з'ясовано, що патологічний процес охоплює як малі так і великі суглоби, при цьому запалення у ділянці суглобів відсутнє. При цьому хвора заперечувала лихоманку, озноб, підвищене нічне потовиділення, втрату ваги та будь-які інші симптоми. Також пацієнтка стверджувала, що не приймала жодних ліків.

Об'єктивно: зріст становив 144 см, вага - 42 кг, індекс маси тіла 21 кг/м2. Зовнішній вигляд без особливостей, шкірні висипання відсутні. При огляді був виявлений на правій руці симптом «барабанних паличок». Цікавим $є$ те, що даний симптом був відсутній на пальцях лівої руки та пальцях обох ніг. Пульс на променевій, ліктьовій та плечовій артеріях правої руки був ледве відчутний, тоді як на лівій руці пальпувався у межах норми. Артеріальний тиск не реєструвався в правій руці, а на лівій становив 112/88 мм рт.ст. Пульс на сонних та стегнових артеріях пальпувались у нормальному обсязі. При перкусії та аускультації серця не було виявлено ніяких особливостей, як і зі сторони дихальної системи.

Надалі були призначені лабораторні методи дослідження. Загальний аналіз крові виявив нейтрофільний лейкоцитоз, легку нормоцитарну нормохромну анемію та тромбоцитоз. Швидкість осідання еритроцитів (ШОЕ) становила $>110$ мм/год, а С-реактивний білок (СРБ) складав - 24 ммоль/л. Дослідження згортання крові, включаючи протромбіновий час, тромбіновий час та активований частковий тромбіновий час, були нормальними. Функції печінки та нирок, електроліти в сироватці крові, включаючи кальцій i магній, та функції щитовидної залози були нормальними. Анти-кардіоліпінові антитіла IgM, вовчак антикоагулянт, анти-бета-2 глікопротеїн $\operatorname{IgG}$ та антитіла IgM були негативними. 
Антиядерні антитіла (ANA), анти-дволанцюгова ДНК (anti ds DNA), цитоплазматичні антинейтрофільні цитоплазматичні антитіла (ANCA) та перинуклеарні ANCA - були негативними.

При проведені рентгенограми грудної клітини та хребта не було виявлено жодних відхилень від норми. Але на аортограмі комп'ютерної томографії (КТ) виявлено тромбоз плечоголовного стовбура, правої загальної сонної, підключичної та пахвових артерій.

Магнітно-резонансну ангіограму (МРА) проводили для подальшого виявлення причини тромбозу. У МРА брахіо-цефалічна артерія була повністю закупорена від ії початку. Також були виявлені колатеральні судини, сформовані дистальніше плечоголовного стовбуру.

Враховуючи клінічну картину, підвищені маркери запалення та МРангіографічні дані, був виставлений діагноз артеріїт Такаясу плечоголовної артерії та ії гілок.

Лікування складалось 3 внутрішньовенного введення метилпреднізолону по 500 мг щодня протягом 3 днів 3 подальшим переходом на пероральний прийом преднізолону у дозі 40 мг щодня. Також хвора отримувала азатіоприн 50 мг на добу та варфарин у дозі 4 мг щодня.

Після початку лікування іï симптоми регресували, але й через 3 місяці від початку терапії симптом «барабанних паличок» на правій руці зберігався. На даний момент хвора знаходиться на диспансерному обліку 3 щомісячним моніторингом 3 оцінкою клінічних симптомів, маркерів запалення та візуалізації.

Висновки. Аретріїт Такаясу - це гранулематозний васкуліт великих судин із неспецифічними симптомами 3 початку захворювання, які можна легко не помітити. Ранні симптоми захворювання включають головний біль, лихоманку, втрату ваги, міалгію та артралгію. Поширеною $\epsilon$ гіпертонія, яка виникає у $80 \%$ випадків через стеноз ниркових артерій, що призводить до активації ренін-ангіотензин-альдостеронової системи [1, с. 53].

Типовими особливостями АТ $є$ також кульгавість кінцівок, каротидні або підключичні артеріальні ушкодження та ішемія кінцевих органів, які зазвичай виникають із прогресуванням захворювання. Показники запалення, такі як ШОЕ та СРБ, підвищені у більшості, але не у всіх пацієнтів з ТА [1, с. 64].

Нами був розглянутий випадок АТ з нетиповими проявами, оскільки у даної пацієнтки з класичних симптомів була наявна лише артралгія та характерні зміни крові. Натомість, був присутній симптом «барабанних паличок», але лише на одній кінцівці, що робить його особливим вираженням хвороби. 
Слід наголосити, що односторонній симптом «барабанних паличок» надзвичайно рідкісний прояв артериїту Такаясу [3, с. 52]. Отже, виявлення даного процесу лише 3 однієї сторони повинно викликати клінічну настороженість 3 підозрою на АТ та негайною діагностикою 3 початком лікування.

\title{
Література:
}

1. Russo RAG, Katsicas MM. Takayasu arteritis. Front Pediatr. 2018;6:265.

2. Hellmich B, et al. 2018 update of the EULAR recommendations for the management of large vessel vasculitis. Ann Rheum Dis. 2020;79(1):19-30.

3. Spicknall KE, Zirwas MJ, English JC III. Clubbing: an update on diagnosis, differential diagnosis, pathophysiology, and clinical relevance. J Am Acad Dermatol. 2005;52(6):1020-8.

DOI https://doi.org/10.30525/978-9934-26-075-9-21

\section{ВПЛИВ ФЕНОМЕНУ ЗВИВИСТОСТІ ПУПКОВОГО КАНАТИКА НА ПАТОЛОГІЮ ПЛОДА}

\author{
Пилипчук I. C. \\ кандидат медичних наук, \\ асистент кафедри акушерства та гінекологї \\ Львівський начіональний медичний університет \\ імені Данила Галищького \\ Флуд В. В. \\ кандидат медичних наук, \\ асистент кафедри акушерства та гінекології \\ Львівський начіональний медичний університет \\ імені Данила Галицького \\ м. Львів, Украӥна
}

Пупковий канатик - це невід'ємна частина посліду, поєднує плід, який розвивається 3 плацентою для підтримки його живильними речовинами, елімінації продуктів життєдіяльності, обміну газів. Пупковий канатик людини містить дві артерії, які несуть деоксигеновану кров від плода до плаценти, і велику вену пуповини, через яку до плода надходить оксигенована кров. Між двома артеріями розташовуються 